\title{
QUALITY OF ROASTED BARU ALMONDS STORED IN DIFFERENT PACKAGES
}

\author{
Dayane Stéphanie FERNANDES ${ }^{1}$, Juliana Rodrigues DONADON ${ }^{2 *}$ (D), Thiago Freitas RANGEL ${ }^{3}$, \\ Rita de Cássia Avellaneda GUIMARÃES ${ }^{4}$, Raquel Pires CAMPOS 5 , Liana Baptista de LIMA ${ }^{6}$, Priscila Aiko HIANE
}

\begin{abstract}
The aim of this study was to evaluate the effect of type of packaging and storage time on the quality of roasted baru almonds by checking lipid and bioactive stability. Almonds submitted to roasting were packaged in three different packages: polypropylene (PP); polypropylene + bioriented polypropylene $(\mathrm{PP}+\mathrm{BOPP})$ and polypropylene + polyethylene terephthalate + metallized and polyethylene (PP + PETMET + PE) films. The moisture content was adequate for safe storage. Almonds packed in PP + PETMET + PE film showed lower titratable acidity and oil acidity index values. During storage, acidity increased from 90 days and the acidity index from 120 days. The iodine index was higher in PP + PEMET + PET film, with predominance of unsaturated fatty acids. The content of total phenols did not differ in almonds, regardless of packaging used. The content of tannins showed reduction after 120 days of storage in all packages, while the content of phytic acids howed reduction after 90 days. The antioxidant capacity did not differ among samples. Almonds had shelf life of 120 days when packed in PP + PEMET + PET packaging and 90 days in the other types of packaging.
\end{abstract}

Keywords: Dipteryx alata; roasting; plastic films; shelf life; oxidation; bioactive compounds.

Practical Application: The determination of shelf life of food is very important to establish the period of time for maintaining physical and chemical quality that may vary according to the film used during storage. There is still no satisfactory knowledge about the effect of the type of packaging associated with storage time on the physico-chemical stability of roasted baru almonds in order to reduce the waste of the processed product, increase profitability and guarantee quality. This information is relevant to the baru processing industry.

\section{Introduction}

Baru (Dipteryx alata Voguel) is a fleshy oval fruit with unique almond, typical of the Brazilian Cerrado biome (Damasceno \& Souza, 2010), popularly known as cumbaru, cumaru, coco-feijão, among other designations (Sano et al., 2004).

Almonds have high protein $\left(22.9100 \mathrm{~g}^{-1}\right)$ and lipid $(40.6 \mathrm{~g}$ $100 \mathrm{~g}^{-1}$ ) content (Santiago et al., 2018) with predominance of oleic (omega-9) and linoleic (omega-3) fatty acids (Siqueira et al., 2016), in addition to high content of phenolic compounds with antioxidant capacity.

Almonds are consumed roasted, since fresh almonds have high phytic acid levels, which sequesters iron and calcium (Fuster et al., 2017). Roasting is a heat treatment that reduces anti-nutritional factors and water available for biochemical reactions, enabling consumption and increasing shelf life (Damiani et al., 2013).

The type of packaging used for seed packaging can influence chemical quality during storage, as water vapor permeability varies according to the film composition, allowing greater or lesser interaction between product and the environment. The plastic film composition also influences permeability to oxygen and light (Siracusa, 2012), factors that trigger oxidative reactions.

The shelf life of roasted baru almonds can vary according to the plastic film used and interactions with the environment due to characteristics of water vapor, oxygen and light permeability. Given the above, this study aimed to evaluate the effect of type of packaging and storage time on the quality of roasted baru almonds.

\section{Material and methods}

Baru fruits were manually collected after natural falling in the municipality of Campo Grande, MS, transported to the Food Technology Unit of UFMS, being manually selected to eliminate spoiled ones and stored in $60-\mathrm{kg}$ raffia bags for 4 months $\left(30^{\circ} \mathrm{C} \pm 1.35 ; 60 \% \pm 1.66\right.$ relative humidity). After this period, almonds were separated from fruits by means of manual

Received 08 June, 2020

Accepted 20 July, 2020

${ }^{1}$ Programa Saúde e Desenvolvimento na Região do Centro-Oeste, Campo Grande, MS, Brasil

${ }^{2}$ Unidade de Tecnologia de Alimentos, Universidade Federal de Mato Grosso do Sul, Campo Grande, MS, Brasil

${ }^{3}$ Faculdade de Ciências Farmacêuticas, Alimentos e Nutrição, Universidade Federal de Mato Grosso do Sul, Campo Grande, MS, Brasil

${ }^{4}$ Programa de Pós-graduação em Saúde e Desenvolvimento na Região Centro-Oeste, Faculdade de Medicina - FAMED, Universidade Federal do Matogrosso do Sul - UFMS, Campo Grande, MS, Brasil

${ }^{5}$ Unidade de Tecnologia de Alimentos e Saúde Pública, Universidade Federal do Matogrosso do Sul - UFMS, Campo Grande, MS, Brasil

${ }^{6}$ Universidade Federal do Mato Grosso do Sul - UFMS, Campo Grande, MS, Brasil

${ }^{7}$ Programa de Pós-graduação em Saúde e Desenvolvimento na Região Centro-Oeste, Faculdade de Medicina - FAMED, Universidade Federal do Matogrosso do Sul - UFMS, Campo Grande, MS, Brasil

${ }^{*}$ Corresponding author: juliana.donadon@ufms.br 
breaker, which presses the pericarp until endocarp rupture and homogenized in Mediza ${ }^{\circledR}$ homogenizer.

Almonds were roasted in oven at $200{ }^{\circ} \mathrm{C}$ for 15 minutes, cooled at room temperature for approximately 10 minutes, and packed in different packages with capacity of $250 \mathrm{~g}$ : Flexible polypropylene (PP) film with $0.02 \mathrm{~mm}$ in thickness; flexible multi-layer polypropylene and bioriented polyethylene (PP + BOPP) film impermeable to water vapor and oxygen with $0.03 \mathrm{~mm}$ in thickness; flexible multi-layer film impermeable to water vapor, oxygen and light composed of polypropylene, metallized polyethylene and polyethylene terephthalate $(\mathrm{PP}+\mathrm{PEMET}+\mathrm{PET})$ with $0.04 \mathrm{~mm}$ in thickness were used. Packages were sealed in pedal sealer (Irmãos Habib) and placed in laboratory environment.

Temperature and relative humidity of the storage environment were monitored using TFA Germany thermohygrometer. Almonds were evaluated for physicochemical parameters at $0,30,60$, 90,120 and 150 days in three repetitions, taken at random and evaluated in triplicate. The experiment was carried out using a completely randomized design (CRD), in a $3 \times 6$ factorial scheme, with three types of packaging and 6 storage times. Averages were compared using the Tukey test at $5 \%$ probability.

When treatment $\mathrm{x}$ storage time interactions were significant, factors within each level of the other factor were analyzed. For comparison purposes, results obtained were converted to $3 \%$ moisture.

The moisture content was evaluated in oven at $105^{\circ} \mathrm{C}$ for 24 hours (Brasil, 2009), while acidity in soluble alcohol and oil acidity, peroxide and iodine levels were evaluated according to methodology of the Instituto Adolfo Lutz (2008).

The oil was extracted using petroleum ether $\left(30-50{ }^{\circ} \mathrm{C}\right)$ as solvent at 1:10 ratio (seed: solvent). Samples with one hundred grams of seeds were ground in mill (Tecnal / TE-631) and packed in filter paper cartridge (J.Prolab / 205ųm) and tied with string. After immersion in solvent for 24 hours, the oil was separated from the miscella in rotary evaporator (Fisatom - 802) under reduced pressure.

After extraction, fatty acids were evaluated according to methodology of Hartman \& Lago (1973) modified by Maia \& Rodriguez-Amaya (1993). Fatty acids were evaluated in Varian gas-liquid chromatograph (mod. CP-3800) with fused silica capillary column with $30 \mathrm{~m}$ in length $\mathrm{x} 0.25 \mathrm{~mm}$ in internal diameter, BPX-70 (70\% Cyanopropyl polysilphenyl siloxane), flame ionization detector (FID) with "split / splitless" injector. Peaks were identified by comparing the retention times of pure patterns of fatty acid methyl esters (Sigma) and quantification performed by area normalization, expressing results in percentage (\%).

Total phenols and antioxidant capacity were determined in hydroethanolic extracts (80\% ethanol) (Roesler et al., 2007). Extracts were evaluated according to Swain \& Hills (1959). The ability to scavenge free radicals was expressed as inhibition percentage. Tannins were determined according to Ial (Instituto Adolfo Lutz, 2008), using hydroethanolic extract (80\% ethanol).
The phytic acid content was determined according to methodology described by Latta \& Eskin (1980), after separation of organic from inorganic phosphorus through an ion exchange column, according to the modified methodology of Harland \& Oberleas (1977).

The shelf life of almonds packed in different packages was defined by observing the results of physicochemical analyses and available legislation, considering them unfit for consumption from the time they lost stability.

\section{Result and discussion}

During the storage of roasted almonds, the maximum temperature remained stable $\left(33.19-33.4^{\circ} \mathrm{C}\right)$ and the minimum temperature showed a small reduction, from $29^{\circ} \mathrm{C}$ to $25^{\circ} \mathrm{C}$ in the first month of storage, while maximum and minimum $\mathrm{RH}$ remained at approximately $68 \%$ and $50 \%$, respectively. After this period, maximum and minimum temperatures tended to decrease until the fourth month of storage (maximum $\mathrm{T}=16.0^{\circ} \mathrm{C}$; minimum $\mathrm{T}=15^{\circ} \mathrm{C}$ ); however, maximum air $\mathrm{RH}$ remained at approximately $50-55 \%$ and minimum $\mathrm{RH}$ at $36 \%$. In the last month of storage, temperature increased by approximately $5{ }^{\circ} \mathrm{C}$ and the air RH remained unchanged. The first month of storage corresponded to March and the last to July.

Almonds packed in PP film showed higher moisture values when compared to the others, which did not differ from one another. During storage, the water content did not change in the first 60 days of storage, but after that period, it showed an increasing trend (Table 1), which was explained by the hygroscopicity of seeds and greater permeability to water vapor in PP film. All packages kept water content below 9\%, recommended for safe storage (Harrington, 1973).

The evaluation of significant interactions (Table 2) revealed that the water content was only lower in almonds packed in $\mathrm{PP}+\mathrm{BOPP}$ and PP + PET MET + PE films at 60 days and 90 days of storage.

Lima et al. (2010) found moisture values for roasted baru almonds of $3.23 \mathrm{~g} 00 \mathrm{~g}^{-1}$, similar to those obtained in the present study (Table 1), while Freitas \& Naves (2010) found higher value, $4.83 \mathrm{~g} 100 \mathrm{~g}^{-1}$, possibly due to the absence of heat treatment, which favors the transfer of water to the environment.

Almonds packed in PP + PET MET + PE films showed lower titratable acidity values (Table 1) at the beginning of storage (Table 2). Regarding time, acidity values were lower at 30 days of storage and higher at 90 days, but after 120-150 days, values were similar to those found at the beginning of storage (Table 1). Belmiro et al. (2010) attributed the increase in acidity in stored pumpkin seeds to lipid degradation, producing free fatty acids.

When evaluating the stability of roasted almonds using results obtained for oil acidity index (Table 1), it was found that almonds packed in PP + PET MET + PE films showed lower values, indicating better preservation of the quality of almond lipids, which may be due to the low permeability of films to water vapor, oxygen and light. However, at the different storage times, films did not differ in terms of acidity (Table 2); however, effect of storage time on lipid quality was observed, with increase in 
Fernandes et al

Table 1. Moisture content, acidity index, peroxide index and iodine index of roasted baru almonds as a function of temperature and storage time.

\begin{tabular}{|c|c|c|c|c|c|}
\hline Packaging & Moisture $^{*}$ & Acidity * & Acidity Index & Peroxide Index & Iodine Index \\
\hline $\mathrm{PP}$ & $3.95 \mathrm{a}$ & $1.29 \mathrm{ab}$ & $0.68 \mathrm{a}$ & $28.79 \mathrm{a}$ & $32.38 \mathrm{~b}$ \\
\hline $\mathrm{PP}+\mathrm{BOPP}$ & $3.58 \mathrm{~b}$ & $1.32^{\mathrm{a}}$ & $0.71 \mathrm{a}$ & $29.94 a$ & $32.86 \mathrm{~b}$ \\
\hline $\mathrm{PP}+\mathrm{PET} \mathrm{MET}+\mathrm{PE}$ & $3.49 \mathrm{~b}$ & $1.23 \mathrm{~b}$ & $0.59 \mathrm{~b}$ & $21.50 \mathrm{~b}$ & $34.94 \mathrm{a}$ \\
\hline F Test & $26.99^{*}$ & $4.60^{\star}$ & $5.49^{*}$ & $13.06^{*}$ & $5.46^{*}$ \\
\hline \multicolumn{6}{|l|}{ Time (days) } \\
\hline 0 & $3.33 b$ & $1.31 \mathrm{~b}$ & $0.49 c$ & $39.50^{\mathrm{a}}$ & $34.1 \mathrm{ac}$ \\
\hline 30 & $3.28 \mathrm{~b}$ & $1.09 \mathrm{c}$ & $0.52 \mathrm{c}$ & $38.16^{\mathrm{a}}$ & $35.08 \mathrm{ad}$ \\
\hline 60 & $3.33 \mathrm{~b}$ & $0.96 \mathrm{~d}$ & $0.62 \mathrm{bc}$ & $32.09^{a}$ & $32.57 \mathrm{bcd}$ \\
\hline 90 & $3.97 \mathrm{a}$ & $1.55 \mathrm{a}$ & $0.62 \mathrm{bc}$ & $17.82 \mathrm{~b}$ & $30.64 b c$ \\
\hline 120 & $4.07 \mathrm{a}$ & $1.34 \mathrm{~b}$ & $0.69 \mathrm{~b}$ & $14.05 \mathrm{~b}$ & $30.83 \mathrm{bc}$ \\
\hline 150 & $4.08 \mathrm{a}$ & $1.43 \mathrm{ab}$ & $1.01 \mathrm{a}$ & $18.85 b$ & $37.15 a$ \\
\hline F Test & $35.84^{*}$ & $43.14^{*}$ & $24.6^{*}$ & $38.90^{*}$ & $9.51^{\star}$ \\
\hline Treatment $\mathrm{x}$ time & $2.13^{*}$ & $4.65^{\star}$ & $1.19 \mathrm{NS}$ & $7.84^{\star}$ & $4.85^{\star}$ \\
\hline $\mathrm{CV}(\%)$ & 6.54 & 3.12 & 9.09 & 17.09 & 4.07 \\
\hline
\end{tabular}

Means followed by at least one lowercase letter in columns do not differ by the Tukey's test $(\mathrm{P}<0.05) .{ }^{*}$ Calculation, sample with $3 \%$ moisture. Moisture $(\%)$; Acidity ( $\mathrm{mL}$ of $100 \mathrm{~g}{ }^{-1} \mathrm{v} /$ $\mathrm{m} \mathrm{M}$ solution); Acidity index $\left(\mathrm{mg} \mathrm{KOHg}^{-1}\right)$; peroxide index (meq $\left.\mathrm{O} 2 \mathrm{Kg}^{-1}\right)$; iodine index $\left(\mathrm{gI}^{100 \mathrm{~g}^{-1}}\right)$.

Table 2. Evaluation of significant treatments $\mathrm{x}$ time interactions obtained for moisture, acidity, peroxide and iodine indexes of roasted baru almonds packed in different packages.

\begin{tabular}{|c|c|c|c|c|c|c|}
\hline \multirow{2}{*}{ Packaging } & \multicolumn{5}{|c|}{ Storage time (days) } & \multirow[b]{2}{*}{150} \\
\hline & 0 & 30 & 60 & 90 & 120 & \\
\hline \multicolumn{7}{|l|}{ Moisture } \\
\hline PP & $3.35 \mathrm{bA}$ & $3.57 \mathrm{bA}$ & 3.79abA & $4.35 \mathrm{aA}$ & $4.31 \mathrm{aA}$ & $4.34 \mathrm{aA}$ \\
\hline $\mathrm{PP}+\mathrm{BOPP}$ & $3.26 \mathrm{bcA}$ & $3.18 \mathrm{cA}$ & $3.12 \mathrm{cB}$ & $3.87 \mathrm{abB}$ & $4.16 \mathrm{aA}$ & $3.88 \mathrm{aA}$ \\
\hline $\mathrm{PP}+\mathrm{PET} \mathrm{MET}+\mathrm{PE}$ & $3.38 \mathrm{bcdA}$ & $3.10 \mathrm{bdA}$ & $3.06 \mathrm{~dB}$ & $3.68 \mathrm{abcB}$ & $3.73 \mathrm{adA}$ & 4.01a A \\
\hline \multicolumn{7}{|l|}{ Acidity } \\
\hline PP & $1.47 \mathrm{aA}$ & $1.24 \mathrm{abA}$ & $0.95 \mathrm{bA}$ & $1.50 \mathrm{aA}$ & $1.28 \mathrm{aA}$ & $1.34 \mathrm{aA}$ \\
\hline $\mathrm{PP}+\mathrm{BOPP}$ & $1.40 \mathrm{aA}$ & $0.98 \mathrm{bA}$ & $0.96 \mathrm{bA}$ & $1.68 \mathrm{aA}$ & $1.48 \mathrm{aA}$ & $1.45 \mathrm{aA}$ \\
\hline $\mathrm{PP}+\mathrm{PET} \mathrm{MET}+\mathrm{PE}$ & $1.08 \mathrm{Bb}$ & $1.07 \mathrm{bA}$ & $0.96 \mathrm{bA}$ & $1.50 \mathrm{aA}$ & $1.26 \mathrm{abA}$ & $1.50 \mathrm{aA}$ \\
\hline \multicolumn{7}{|l|}{ Acidity index } \\
\hline $\mathrm{PP}+\mathrm{PET} \mathrm{MET}+\mathrm{PE}$ & $0.40 \mathrm{bA}$ & $0.54 \mathrm{bA}$ & $0.52 \mathrm{bA}$ & $0.58 \mathrm{bA}$ & $0.55 \mathrm{bA}$ & $0.94 \mathrm{aA}$ \\
\hline \multicolumn{7}{|l|}{ Peroxide Index } \\
\hline PP & $56.39 \mathrm{aA}$ & $31.13 \mathrm{bcA}$ & $34.55 \mathrm{cA}$ & $19.80 \mathrm{bcA}$ & $14.84 \mathrm{bA}$ & $16.06 \mathrm{bA}$ \\
\hline $\mathrm{PP}+\mathrm{BOPP}$ & $31.66 \mathrm{abB}$ & $44.30 \mathrm{aA}$ & $44.88 \mathrm{aA}$ & $16.91 \mathrm{bA}$ & $18.85 \mathrm{bA}$ & $23.05 \mathrm{bA}$ \\
\hline $\mathrm{PP}+\mathrm{PET} \mathrm{MET}+\mathrm{PE}$ & $30.44 \mathrm{abB}$ & $39.05 \mathrm{aA}$ & $16.84 \mathrm{bcB}$ & $16.76 \mathrm{bcA}$ & $8.46 \mathrm{cA}$ & $17.43 \mathrm{bcA}$ \\
\hline \multicolumn{7}{|l|}{ Iodine index } \\
\hline PP & $34.97 \mathrm{aA}$ & $36.08 \mathrm{aA}$ & $33.33 \mathrm{aA}$ & $28.71 \mathrm{aA}$ & $28.90 \mathrm{aA}$ & $32.31 \mathrm{aB}$ \\
\hline $\mathrm{PP}+\mathrm{BOPP}$ & $32.91 \mathrm{aA}$ & $34.84 \mathrm{aA}$ & $34.49 \mathrm{aA}$ & $31.22 \mathrm{aA}$ & $28.20 \mathrm{aA}$ & $35.51 \mathrm{aB}$ \\
\hline
\end{tabular}

Means followed by at least one lowercase letter in rows and at least one uppercase letter in columns do not differ from each other by the Tukey test $(\mathrm{P}<0.05)$. Moisture $(\%)$; Acidity ( $\mathrm{mL}$ of $100 \mathrm{~g}^{-1} \mathrm{~V} / \mathrm{m} \mathrm{M}$ solution); Acidity index $\left(\mathrm{mg} \mathrm{KOHg}^{-1}\right)$; peroxide index (meq O2 $\left.\mathrm{Kg}^{-1}\right)$; iodine index $\left(\mathrm{gI}^{100 \mathrm{~g}^{-1}}\right.$ ). 
the acidity index after 120 days of storage (Table 1), indicating oil degradation after this period. According to the Adolfo Lutz Institute, the acidity index determines the oil's conservation status (Instituto Adolfo Lutz, 2008).

Almonds packed in PP and PP + BOPP films had higher peroxide index values, indicating greater lipid oxidation (Table 1), while PP + PET MET + PE was more efficient in reducing oil degradation due to its impermeability to light, with values that approached those recommended by legislation (Brasil, 2005) in the period from 60 to 150 days.

When evaluating the effect of storage time, it was found that lipid oxidation was higher in the first 60 days of storage, which can be explained by the process of initiation and propagation of lipid oxidation, stages with intense production and propagation of free radicals. After this period, it decreased (Tables 1 and 2), which is explained by the lipid oxidation reduction (Sevanian \& Hochstein, 1985) induced by the action of light or high temperatures (Instituto Adolfo Lutz, 2008).

Siqueira et al. (2016) analyzed baru oil from fresh almonds and found acidity index values of $0.28 \mathrm{mg} \mathrm{KOH} \mathrm{g}^{-1}$ and peroxide values of $1.61 \mathrm{meq} 2 \mathrm{Kg}^{-1}$, which are lower than those obtained for oil extracted from roasted almonds (Table 1), possibly due to the high roasting temperature.

The acidity index for olive oil must reach maximum of $1 \mathrm{~g}^{100 \mathrm{~g}^{-1}}$ in oleic acid and $15 \mathrm{meq} \mathrm{kg}^{-1}$ in peroxide index (Brasil, 2005). Comparing these values with results obtained in this study, baru almond oil showed values within the limit established by legislation for acidity; however, for peroxide, values found were higher. It is not possible to state that baru almonds are unsuitable for consumption as there is no specific legislation for edible roasted seeds such as baru and peanut.

The iodine index values, which measure the degree of oil unsaturation (Instituto Adolfo Lutz, 2008), were higher in almond oil packed in PP + PET MET + PE film (Table 1), demonstrating that the oxidative process was lower. During storage, values ranged

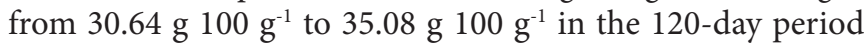
and showed small increase after this period $\left(37.15{\left.\mathrm{~g} 100 \mathrm{~g}^{-1}\right)}^{-1}\right.$ (Table 1). The evaluation of significant interactions revealed that this occurred in almond oil packed in water vapor and light proof packaging (PP + PET MET + PE) (Table 2). Siqueira et al.

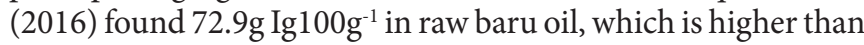
that found in roasted almond oil (Table 1).

Fatty acids found in higher percentage in roasted baru almonds were oleic (C18: 1n9t and C18: $1 \mathrm{n} 9 \mathrm{c})$ and linoleic acids (C18: $2 \mathrm{n} 6 \mathrm{c}$ ), with average values of $24.93 \%, 22.45 \%$ and $29.94 \%$, respectively, whose contents did not differ among packages (Table 3). During the storage of almonds, linoleic acid levels did not change, indicating that they were preserved, while those of oleic acid (C18: $1 \mathrm{n} 9 \mathrm{t}$ and C18: $\ln 9 \mathrm{c})$ fluctuated over time (Tables 3). Table 3 shows that when C18: 1 n9t oleic acid decreased during storage, C18: 1n9c oleic acid increased in the same period.

Oleic acids are monounsaturated and according to Alves et al. (2016), monounsaturated compounds are known for their beneficial health properties related to the reduction of cardiovascular disease risks (Alves et al., 2016).

Vera et al. (2009) analyzed the chemical characteristics of fresh baru almonds and found average of $47.15 \mathrm{~g} 100 \mathrm{~g}^{-1}$ for oleic

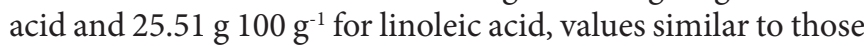
obtained in roasted baru almonds (Table 4), corroborating Siqueira et al. (2016), who found predominance of oleic acid (49.2\%), followed by linoleic acid (27.3\%), which are significant amounts for human health.

Oleic acids are also called as omega- 9 and linoleic acids as omega-6, while linolenic acids as omega-3. The World Health Organization (Organización Mundial de La Salud, 2003) recommends omega-6: omega-3 ratio from 5: 1 to 10: 1 to reduce the risk of

Table 3. Profile of the main unsaturated fatty acids present in roasted baru almonds packed in different packages and stored for up to 150 days.

\begin{tabular}{|c|c|c|c|c|c|c|}
\hline Packaging & $\mathrm{C} 18 \mathrm{ln} 9 \mathrm{c}$ & $\mathrm{C} 18: \ln 9 \mathrm{t}$ & $\mathrm{C} 18: 2 \mathrm{n} 6 \mathrm{c}$ & $\mathrm{C} 18: 3 \mathrm{n} 3$ & $\mathrm{C} 20: 3 \mathrm{n} 3$ & $\mathrm{C} 22: \ln 9$ \\
\hline $\mathrm{PP}$ & $23.41 \mathrm{a}$ & $24.8 \mathrm{a}$ & $29.24 \mathrm{a}$ & $0.4 \mathrm{a}$ & $1.44 \mathrm{a}$ & $0.13 a$ \\
\hline $\mathrm{PP}+\mathrm{BOPP}$ & $19.15 a$ & $24.75 a$ & $29.7 \mathrm{a}$ & $0.3 \mathrm{a}$ & $1.34 \mathrm{a}$ & $0.15 \mathrm{a}$ \\
\hline $\mathrm{PP}+\mathrm{PET} \mathrm{MET}+\mathrm{PE}$ & $24.8 \mathrm{a}$ & $25.24 \mathrm{a}$ & $30.9 a$ & $0.5 \mathrm{a}$ & $1.44 \mathrm{a}$ & $0.32 \mathrm{a}$ \\
\hline F Test & $1.55 \mathrm{NS}$ & $0.008 \mathrm{NS}$ & $0.45 \mathrm{NS}$ & $1.6 \mathrm{NS}$ & $0.07 \mathrm{NS}$ & $1.6 \mathrm{NS}$ \\
\hline \multicolumn{7}{|l|}{ Time (days) } \\
\hline 0 & $49.13 a$ & $0 \mathrm{~b}$ & $29.8 \mathrm{a}$ & $0.11 \mathrm{~b}$ & $0 \mathrm{~b}$ & $0.24 \mathrm{a}$ \\
\hline 30 & $0.23 b$ & $38.75 \mathrm{a}$ & $32.2 \mathrm{a}$ & $0.38 \mathrm{ab}$ & $2.01 \mathrm{a}$ & $0.07 \mathrm{a}$ \\
\hline 60 & $43.35 \mathrm{a}$ & $5.5 \mathrm{~b}$ & $29.5 \mathrm{a}$ & $0.28 \mathrm{ab}$ & $0.9 \mathrm{ab}$ & $0.51 \mathrm{a}$ \\
\hline 90 & $38.9 \mathrm{a}$ & $5.61 \mathrm{~b}$ & $26.2 \mathrm{a}$ & $0.26 \mathrm{ab}$ & $2.06 \mathrm{a}$ & $0.21 \mathrm{a}$ \\
\hline 120 & $2.9 \mathrm{~b}$ & $43.63 \mathrm{a}$ & $31.7 \mathrm{a}$ & $0.66 \mathrm{a}$ & $1.84 \mathrm{a}$ & $0.063 \mathrm{a}$ \\
\hline 150 & $0.22 \mathrm{~b}$ & $46.1 \mathrm{a}$ & $30.22 \mathrm{a}$ & $0.61 \mathrm{a}$ & $1.65 \mathrm{a}$ & $0.1 \mathrm{a}$ \\
\hline Test & $50^{*}$ & $29^{*}$ & $1.43 \mathrm{NS}$ & $5.02^{*}$ & $6.53^{\star}$ & $2.08 \mathrm{NS}$ \\
\hline Treat $\mathrm{x}$ time & $2.61^{\star}$ & $1.15 \mathrm{NS}$ & $1.14 \mathrm{NS}$ & $2.41^{*}$ & $1.16 \mathrm{NS}$ & $0.95 \mathrm{NS}$ \\
\hline CV(\%) & 13.09 & 1.08 & 2.87 & 175 & 3.55 & 50 \\
\hline
\end{tabular}

Means followed by at least one lowercase letter in columns does not differ using the Tukey test $(\mathrm{P}<0.05)$. ${ }^{\star}$ Calculation, sample with $3 \%$ moisture. NS: not significant. Fatty acids: $g$ 100 ${ }^{-1}$. 
development of cardiovascular diseases (Marin et al., 2009). This ratio was 150: 1 in roasted baru almonds.

In a study with animal model, Fernandes et al. (2015) observed that the addition of roasted baru almonds in the diet prevented hyperlipidemia and lipid peroxidation in the liver tissue, providing protection against high cholesterol and saturated fat intake, as it has high levels of unsaturated fatty acids in its lipid profile.

Baru almond lipids showed average values of $6.08 \%$ of palmitic acid (C16: 0) and 4.75\% of lignoceric acid (C24: 0). These values also did not differ among packages, but during storage, it was found that palmitic acid values fluctuated over time and lignoceric acid values remained unchanged (Tables 4).

In smaller proportions and considering the interval between 0.3 to $4.0 \%$, baru almonds presented the following acids: C18: 0 (2.90\%), C20: 1 (1.85\%), C20: 3n3 (1.41\%), C22: 0 (1.13\%), C18: $3 n 3(0.40 \%)$ and C20: $0(0.39 \%)$ (Tables 3 and 4$)$. These contents did not differ between packages and storage times, except for C20: $3 \mathrm{n} 3$ acid, whose contents showed an increasing trend after 30 days of storage (Table 3), and for C20: 0 , a reduction after 90 days of storage (Table 4 ).

In irrelevant percentages, amino acids found were: $\mathrm{C} 4: 0$ (0.12\%), C6: 0 (0.007\%), C14: 0 (0.0009\%), C16: 1 (0.009\%), C17: 0 (0.03\%), C18: 2n6t (0.002\%), C18: 3n6 (0.0002\%), C20: 2 (0.0026\%), C22: 0, C22: 1n9 (0.20\%), C20: 5 n3 (0.01\%), C23: 0 (0.046\%), C22: 2 (0.023\%), C24: $\ln 9(0.024 \%)$.

The levels of total phenols did not differ in roasted almonds, regardless of packaging used. During the storage period, a decrease in this compound was observed after 90 days (Table 5). In the evaluation of significant interactions, this reduction occurred in almonds packed in PP and PP + PET MET + PE films at 120 days and 30 days of storage, respectively (Table 6). In PP + BOPP films, values did not change over time (Table 6), indicating greater efficiency in the preservation of this bioactive compound. This packaging is permeable to light, and to preserve the phenolic content, transparent packaging can be used.

Siqueira et al. (2012) found $154.6 \mathrm{mg} 100 \mathrm{~g}^{-1}$ of total phenols in baru almonds, a value lower than that found in this study during storage for up to 60 days, but over time, values came close, while Santiago et al. (2018) obtained higher values $728 \mathrm{mg}$ GAE $100 g^{-1}$ ).

When evaluating the effect of type of packaging on the content of total phenols in lyophilized pequi pulp stored for 180 days, Nascimento et al. (2016) found that polypropylene + polyethylene terephthalate packaging was the most effective in preservation. The other packages tested were: transparent polyethylene and polyethylene containing aluminum foil.

Almonds packed in PP + BOPP and PP + PET MET + PE films showed lower tannin values compared to those packed in PP films, which has less added value. As observed for total phenols, the levels of tannins decreased after 120 days of storage (Table 5), regardless of packaging (Table 6). Tannins are phenolic compounds, indicating that the reduction in total phenol content (Table 5) can be explained by the reduction in tannin content.

Phytic acid content in almonds packed in PP and PP + BOPP films was higher (Table 5) at 120 days of storage (Table 6). These levels showed reduction after that period (Table 5), regardless of packaging (Table 6), but after 150 days of storage, they increased again in the PP + PE + MET PET packaging, with values that did not differ from those obtained at the beginning of storage (Table 6).

Phytic acid and tannins are considered anti-nutritional factors (Damiani et al., 2013). In large amounts, phytates can complex with some minerals reducing absorption by the body. However, balanced diet is unlikely to have harmful effects since the inhibition of mineral absorption is offset by the presence of other nutrients such as ascorbic acid and other organic acids that

Table 4. Profile of the main saturated fatty acids present in roasted baru almonds packed in different packages and stored for up to 150 days.

\begin{tabular}{|c|c|c|c|c|c|c|}
\hline Packaging & $\mathrm{C} 16: 0$ & C18:0 & C20:0 & C20:1 & $\mathrm{C} 22: 0$ & C24:0 \\
\hline $\mathrm{PP}$ & $6.29 \mathrm{a}$ & $3 a$ & $0.34 \mathrm{a}$ & $1.9 \mathrm{a}$ & $0.84 \mathrm{a}$ & $6.8 \mathrm{a}$ \\
\hline $\mathrm{PP}+\mathrm{BOPP}$ & $5.62 \mathrm{a}$ & $2.8 \mathrm{a}$ & $0.41 \mathrm{a}$ & $1.71 \mathrm{a}$ & $0.7 \mathrm{a}$ & $2.4 \mathrm{a}$ \\
\hline $\mathrm{PP}+\mathrm{PET} \mathrm{MET}+\mathrm{PE}$ & $6.33 \mathrm{a}$ & $3 a$ & $0.43 \mathrm{a}$ & $1.94 \mathrm{a}$ & $2.6 \mathrm{a}$ & $5.07 \mathrm{a}$ \\
\hline F Test & $1.6 \mathrm{NS}$ & $0.6 \mathrm{NS}$ & $0.56 \mathrm{NS}$ & $0.71 \mathrm{NS}$ & $1.06 \mathrm{NS}$ & $0.7 \mathrm{NS}$ \\
\hline \multicolumn{7}{|l|}{ Time (days) } \\
\hline 0 & $6.2 \mathrm{ab}$ & $3.26 \mathrm{a}$ & $0.85 \mathrm{a}$ & $2 \mathrm{a}$ & $2.7 \mathrm{a}$ & $3.43 \mathrm{a}$ \\
\hline 30 & $7.03 \mathrm{a}$ & $3 a$ & $0.26 \mathrm{bc}$ & $1.8 \mathrm{a}$ & $0 \mathrm{a}$ & $2.3 \mathrm{a}$ \\
\hline 60 & $6.25 \mathrm{ab}$ & $3.04 \mathrm{a}$ & $0.67 \mathrm{a}$ & $2.2 \mathrm{a}$ & $5.11 \mathrm{a}$ & $7.8 \mathrm{a}$ \\
\hline 90 & $5.55 \mathrm{ab}$ & $2.9 \mathrm{a}$ & $0.55 \mathrm{ac}$ & $1.9 \mathrm{a}$ & $0.46 \mathrm{a}$ & $3.09 \mathrm{a}$ \\
\hline 120 & $6.62 \mathrm{ab}$ & $3.1 \mathrm{a}$ & $0.05 b$ & $1.82 \mathrm{a}$ & $0 \mathrm{a}$ & $1.7 \mathrm{a}$ \\
\hline 150 & $4.84 \mathrm{~b}$ & $2.44 \mathrm{a}$ & $0 \mathrm{~b}$ & $1.36 \mathrm{a}$ & $0 \mathrm{a}$ & $10.25 a$ \\
\hline F Test & $3.03^{*}$ & $1.2 \mathrm{NS}$ & $16.06^{*}$ & $1.9 \mathrm{NS}$ & $2.08 \mathrm{NS}$ & $0.84 \mathrm{NS}$ \\
\hline Treat $\mathrm{x}$ tempo & 1. $01 \mathrm{NS}$ & $0.7 \mathrm{NS}$ & $2.11^{*}$ & $0.91 \mathrm{NS}$ & $1.43 \mathrm{NS}$ & $1.16 \mathrm{NS}$ \\
\hline CV(\%) & 6.58 & 3.75 & 10.25 & 5.4 & 76 & 46.5 \\
\hline
\end{tabular}

Means followed by at least one lowercase letter in columns do not differ using the Tukey test $(\mathrm{P}<0.05) .{ }^{*}$ Calculation, sample with $3 \%$ moisture. NS: not significant. Fatty acids: $g$ 100 ${ }^{-1}$. 
Table 5. Phenolic compounds, tannins, phytic acid and antioxidant activity of roasted baru almonds stored in three different packages for a period of 150 days.

\begin{tabular}{|c|c|c|c|c|}
\hline Packaging & Phenols & Tannins & Phytic acid & Antioxidant activity \\
\hline PP & $213.29 a$ & $403.38 \mathrm{a}$ & $546.20 \mathrm{ab}$ & $56.74 \mathrm{a}$ \\
\hline $\mathrm{PP}+\mathrm{BOPP}$ & $177.07 \mathrm{a}$ & $323.05 b$ & $595.10^{\mathrm{a}}$ & $58.86 \mathrm{a}$ \\
\hline $\mathrm{PP}+\mathrm{PET}+\mathrm{MET}+\mathrm{PE}$ & $173.27 \mathrm{a}$ & $315.22 b$ & $464.92 b$ & $63.97 \mathrm{a}$ \\
\hline Teste F F Test & $3.19 \mathrm{NS}$ & $19.18^{\star}$ & $6.22^{\star}$ & $1.93 \mathrm{NS}$ \\
\hline \multicolumn{5}{|l|}{ Time (days) } \\
\hline 0 & $279.09 \mathrm{a}$ & $460.07 a$ & $607.16 a$ & $63.27 \mathrm{c}$ \\
\hline 30 & $231.67 \mathrm{ac}$ & $500.83 a$ & $624.60 \mathrm{a}$ & $81.26 \mathrm{ab}$ \\
\hline 60 & $200.50 \mathrm{ad}$ & $462.73 a$ & $666.28 \mathrm{a}$ & $40.22 \mathrm{e}$ \\
\hline 90 & $141.24 \mathrm{bd}$ & $469.10 \mathrm{a}$ & $643.84 a$ & $45.09 \mathrm{dc}$ \\
\hline 120 & $159.72 \mathrm{bcd}$ & $118.88 b$ & $423.91 b$ & $71.95 b c$ \\
\hline 150 & $124.06 \mathrm{~b}$ & $71.69 \mathrm{~b}$ & $297.29 b$ & $57.34 \mathrm{~cd}$ \\
\hline F Test & $10.40^{*}$ & $155.09^{*}$ & $15.89^{*}$ & $17.17^{\star}$ \\
\hline Treatment $\mathrm{x}$ time & $2.83^{\star}$ & $2.92^{*}$ & $2.47^{\star}$ & $1.3 \mathrm{NS}$ \\
\hline $\mathrm{CV}(\%)$ & 11.76 & 14.05 & 12.28 & 6.19 \\
\hline
\end{tabular}

Means followed by at least one lowercase letter in columns do not differ by the Tukey test $(\mathrm{P}<0.05) .{ }^{*}$ Calculation, sample with $3 \%$ moisture. Phenols: mg GAE $100 \mathrm{~g}{ }^{-1}$; Tannins: $\mathrm{mg}$ tannic acid $100 \mathrm{~g}^{-1}$; phytic acid: mg PA $100 \mathrm{~g}^{-1}$; Antioxidant: \% inhibition.

Table 6. Variation in the phenol, tannins and phytic acid indexes of baru almonds submitted to roasting and stored for up to 150 days.

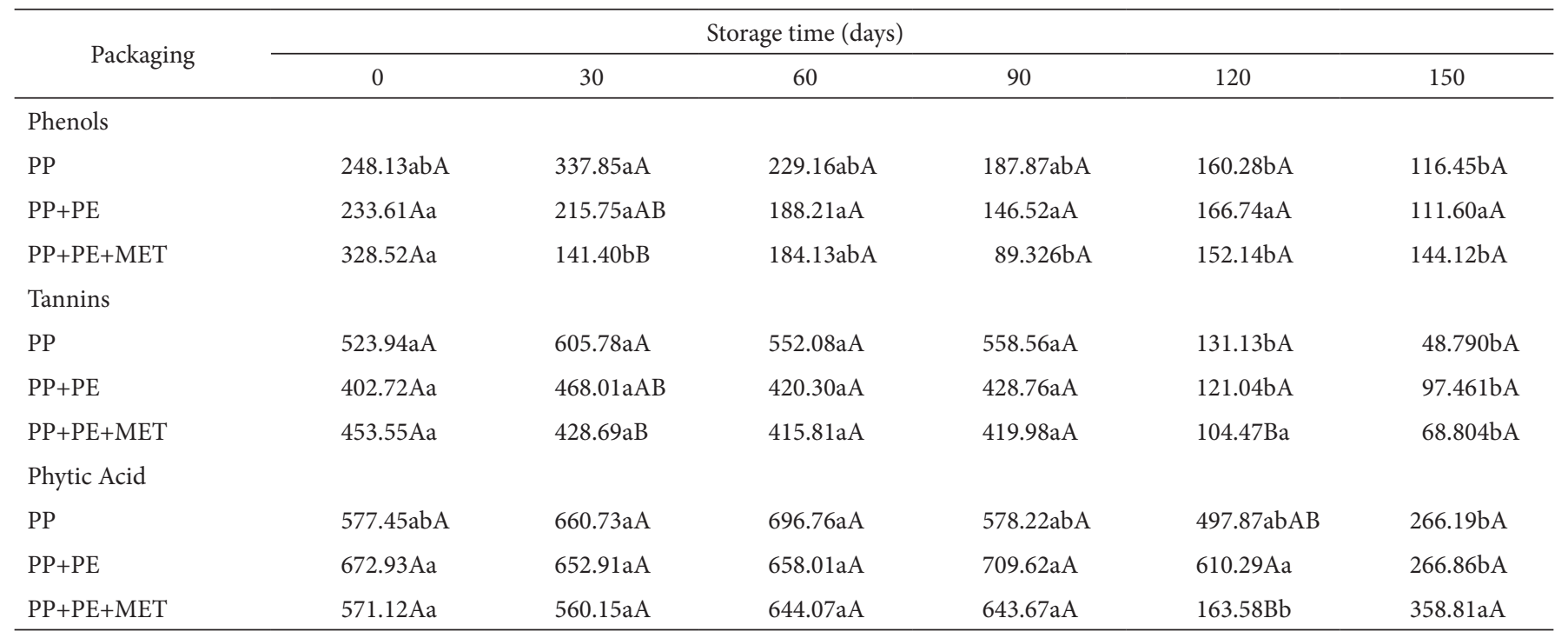

Means followed by at least one lowercase letter in rows and at least one uppercase letter in columns do not differ from each other by the Tukey test $(\mathrm{P}<0.05)$. Phenols: $\mathrm{mg}$ GAE $100 \mathrm{~g}{ }^{-1}$; Tannins: $\mathrm{mg}$ tannic acid $100 \mathrm{~g}^{-1}$; phytic acid: $\mathrm{mg}$ PA $100 \mathrm{~g}^{-1}$; Antioxidant: \% inhibition.

will compete with phytic acid for binding with these minerals (Fuster et al., 2017).

In some cases, tannins are also considered anti-nutritional agents, as they have the ability to form complexes, mainly with proteins, reducing their digestibility (Naves et al., 2010). However, their presence in food is more related to health benefits, such as anti-inflammatory, anti-infectious and protective effects against oxidative stress associated with the development of diseases such as cancer, cardiovascular and degenerative diseases (Del Rio et al., 2013).
Marin et al. (2009) found phytic acid values of $1073.6 \mathrm{mg}$ $100 \mathrm{~g}^{-1}$ in fresh baru almonds, values higher than those found in

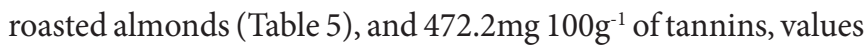
close to those obtained in the present study during storage for up to 90 days (Table 5). It is important to observe that the roasting process reduces this content. High phenols and phytic acid levels found in the composition of baru almond may be responsible for its antioxidant effect (Siqueira et al., 2012).

Antioxidant activity values found in roasted baru almonds, expressed as inhibition percentage, did not show significant 
differences, regardless of packaging. During storage, the antioxidant activity values varied over time (Table 5).

Siqueira et al. (2017) analyzed the antioxidant capacity of guapeva fruits, also present in the Brazilian Cerrado biome, and

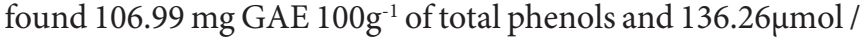
trolex of antioxidant capacityin seeds. The contents of phenols are lower than those found in roasted almonds (Table 5), indicating that baru stands out in relation to guapeva seeds as source of total phenols, considered bioactive compounds.

The presence of antioxidants in food brings health benefits by fighting free radicals produced by the body. The imbalance between the production of free radicals and antioxidants leads to oxidative stress, which causes several diseases such as cardiovascular, degenerative, tumors, among others (Siqueira et al., 2017). Thus, it is important to consume foods sources of these nutrients, such as baru, in order to prevent various diseases and improve biological development.

\section{Conclusion}

Lipid stability was better preserved in PP + PE MET + PET film, while PP was more efficient in preserving bioactive compounds (phytic acid and tannins). Almonds had shelf life of 120 days when packed in PP + PE MET + PET films and of 90 days in the other films. Unsaturated oleic (C18: 1n9t), oleic (C18: 1n9c) and linoleic (C18: 2n6c) fatty acids were preserved during storage.

\section{Acknowledgements}

We would like to thank CNPq for process No. 409183 / 2016-4 for financing this work and "UniãoIndústria e Comércio de PlásticosLtda” for donating the packages.

\section{References}

Alves, A. M., Fernandes, D. C., Borges, J. F., Sousa, A. G. O., \& Nave, M. M. V. (2016). Oilseeds native to the cerrado have fatty acid profile beneficial for cardiovascular health. Revista de Nutrição, 29(6), 859866. http://dx.doi.org/10.1590/1678-98652016000600010.

Belmiro, T. M. C., Queiroz, A. J. M., Figueirêdo, R. M. F., Fernandes, T. K. S., \& Bezerra, M. C. T. (2010). Alterações químicas e físicoquímicasemgrãos de abóboradurantes o armazenamento. Revista Brasileira de Engenharia Agrícola e Ambiental, 14(9), 1000-1007. http://dx.doi.org/10.1590/S1415-43662010000900013.

Brasil, Ministério da Agricultura e Reforma Agrária. (2009). Secretaria Nacional de defesa Agropecuária. Regras para análise de sementes. Brasília: Ministério da Agricultura e Reforma Agrária, 399 p.

Brasil, Ministério da Saúde. (2005, Setembro 22). Resolução RDC $\mathrm{n}^{\circ} 270$. Regulamento técnico para óleos vegetais, gorduras vegetais e creme vegetal. Diário Oficial [da] República Federativa do Brasil.

Damasceno, G. A. Jr, \& Souza, P. R. (2010). Sabores do Cerrado \& Pantanal: receitas e boaspráticas de aproveitamento. Campo Grande, MS: Ed. UFMS. $141 \mathrm{p}$.

Damiani, C., Almeida, T. L., Costa, N. C., Medeiros, N. X., Silva, A. G. M., Silva, F. A., Lage, M. E., \& Becker, F. S. (2013). Perfil de ácidosgraxos e fatoresantinutricionais de amêndoas de pequicrua e torrada. Pesquisa Agropecuária Tropical, 43(1), 71-78. http://dx.doi. org/10.1590/S1983-40632013000100004.

Del Rio, D., Rodriguez-Mateos, A., Spencer, J. P. E., Tognolini, M., Borges, G., \& Crozier, A. (2013). Dietary (poly) phenolics in human health: structures, bioavailability, and evidence of protective affects against chronic diseases. Antioxidants \& Redox Signalling, 18(14), 1818-1892. http://dx.doi.org/10.1089/ars.2012.4581. PMid:22794138.

Fernandes, D. C., Alves, A. M., Castro, G. S. F., Jordão, A. A. Jr, \& Naves, M. M. V. (2015). Effects of baru almond and Brazil nut against hyperlipidemia and oxidative stress vivo. Journal of Food Research, 4(4), 38. http://dx.doi.org/10.5539/jfr.v4n4p38.

Freitas, J. B., \& Naves, M. M. V. (2010). Composiçãoquímica de nozes e sementescomestíveis e suarelação com a nutrição e saúde. Revista de Nutrição, 23(2), 269-279. http://dx.doi.org/10.1590/S141552732010000200010 .

Fuster, JMB, Cortés, PS, Bestard, JP \&Freixedas, FG (2017). Fosfatos de origen vegetal, fitatos y calcificacionespatológicasem la enfermedad renal crónica. Revista de la sociedades panoladenefrologia, 37(1), 20-28.

Harland, B. F., \& Oberleas, D. (1977). A modified method for phytate analysis using na ion-exchange procedure: application to textured vegetable proteins. Cereal Chemistry, 54(4), 827-832.

Harrington, J. (1973). Packaging seed for storage and shipment. Seed Science and Technology, 1(3), 701-709.

Hartman, L., \& Lago, R. C. A. (1973). Rapid preparation of fatty acid methyl esters from lipids. Laboratory Practice, 22(6), 475-476. PMid:4727126.

Instituto Adolfo Lutz - IAL. (2008). Métodos físico-químicos para análise de alimentos. São Paulo: Instituto Adolfo Lutz.

Latta, M., \& Eskin, M. (1980). A simple and rapid method for phytate determination. Journal of Agricultural and Food Chemistry, 28(1), 313-315. http://dx.doi.org/10.1021/jf60232a049.

Lima, J. C. R., Freiras, J. B., Czeder, L. P., Fernandes, D. C., \& Naves, M. M. V. (2010). Qualidade microbiológica, aceitabilidade e valor nutricional de barras de cereais formuladas com polpa e amêndoa de baru. Boletim do Centro de Pesquisa e Processamento de Alimentos, 28(2). http://dx.doi.org/10.5380/cep.v28i2.20450.

Maia, E. L., \& Rodriguez-Amaya, D. B. (1993). Avaliação de um método simples e econômico para a metilação de ácidos graxos com lipídios de diversas espécies de peixes. Revista do Instituto Adolfo Lutz, (53), 27-35.

Marin, A. M., Arruda, S. F., \& Siqueira, E. M. A. (2009). Minerals, phytic acid and tannin contentes of 18 fruits from the Brasilian savanna. International Journal of Food Sciences, 60(1, Suppl. 7upl. Suppl. 7), 180-190. http://dx.doi.org/10.1080/09637480902789342. PMid:19353365.

Nascimento, N. N. R., Alves, A. M., Silva, M. R., \& Naves, M. M. V. (2016). Antioxidant capacity ofpequi (Caryocar brasiliense Camb.) pulp is preserved by freeze-drying and light-resistant packaing. Revista Brasileira de Fruticultura, 39(1). http://dx.doi.org/10.1590/010029452017150.

Naves, L. P., Corrêa, A. D., Santos, C. D., \& Abreu, C. M. P. (2010). Componentes antinutricionais e digestibilidade proteica em sementes de abóbora (Cucurbita máxima) submetidas a diferentes processamentos. Ciência e Tecnologiadealimentos, 30(supl. 1), 180 184. http://dx.doi.org/10.1590/S0101-20612010000500027.

Organización Mundial de La Salud - OMS. (2003). Informe de una consulta mixta de expertos OMS/FAO. Dieta, Nutrición y Prevención de Enfermedades Crónicas (Serie de Informes Técnicos, n. 916). Genebra: OMS.

Roesler, R., Malta, L. G., Carrasco, L. C., Holanda, R. B., Souza, C. A. S., \& Pastore, G. M. (2007). Atividadeantioxidante de frutas do 
cerrado. Food Science and Technology (Campinas), 27(1), 53-60. http://dx.doi.org/10.1590/S0101-20612007000100010.

Sano, S. M., Ribeiro, J. P., \& Brito, M. A. (2004). Baru: biologia e uso (Documentos, 116). Planaltina: Embrapa Cerrados.

Santiago, G. L., Oliveira, I. G., Horst, M. A., Naves, M. M. V., \& Silva, M. R. (2018). Peel and pulp of baru (DipteryxalataVog.) provide high fiber, phenolic contente and antioxidant capacity. Food Science and Technology (Campinas), 38(2), 244-249. http://dx.doi. org/10.1590/1678-457x.36416.

Sevanian, A., \& Hochstein, P. (1985). Mechanisms and consequences of lipid peroxidation in biological systems. Annual Review of Nutrition, 5(1), 365-390. http://dx.doi.org/10.1146/annurev.nu.05.070185.002053. PMid:2992549.

Siqueira, A. P. S., Castro, C. F. S., Silveira, E. V., \& Lourenço, M. F. C. (2016). Chemical quality of Baru almond (Dipteryxalataoil). Ciência Rural, 46(10), 1865-1867. http://dx.doi.org/10.1590/01038478cr20150468.

Siqueira, A. P. S., Oliveira, J. M., Machado, D. R. Jr, \& Lourenço, M. F. C. (2017). Chemical caracterization and antioxidant capacity of guapeva. Revista Brasileira de Fruticultura, 39(Spe). http://dx.doi. org/10.1590/0100-29452017584.

Siqueira, E. M. A., Marin, A. M. F., Cunha, M. S. B., Fustinoni, A. M., de Sant'ana, L. P., \& Arruda, S. F. (2012). Consumption of baru seeds \{DipteryxalataVog.\}, a Brasiliansavana nut, prevents iron-induced oxdative stress in rats. Food Research International, 45(1), 427-433. http://dx.doi.org/10.1016/j.foodres.2011.11.005.

Siracusa, V. (2012). Food packaging permeability behaviour: a report. International Journal of Polymer Science, 2012, 1-11. http://dx.doi. org/10.1155/2012/302029.

Swain, T., \& Hills, W. E. (1959). The phenolic constituents of Prunusdomestica I.: The quantitative analysis of phenolic constituent. Journal of the Science of Food and Agriculture, 10(1), 63-68. http:// dx.doi.org/10.1002/jsfa.2740100110.

Vera, R., Soares, M. S. Jr, Naves, R. V., Souza, E. R. B., Fernandes, E. P., Caliari, M., \& Leandro, W. M. (2009). Característicastípicas de amêndoas de barueiro (DipteryxAlataVog.) de ocorrência natural no cerrado do estado de Goiás, Brasil. Revista Brasileira de Fruticultura, 31(1), 112-118. http://dx.doi.org/10.1590/S0100-29452009000100017. 